DOI: https://doi.org/10.31392/NZ-npu-142.2019.24

УДК 78.091:780.647.2

ORCID id 0000-0001-5100-3656

Стрельченко К. М.

\title{
МЕТОДИКА ВИКОНАННЯ ТВОРІВ НА БАЯНІ ТА АКОРДЕОНІ В ЕСТРАДНО-ДЖАЗОВИХ СТИЛЯХ
}

Суть изієї роботи полягає в практичному застосуванні інноваційного підходу до оновлення конщертного репертуару баяніста i акордеоніста з погляду легкожанровості виконавської програми. В принщипі, це звертання до часів, коли пісенно-танцювальні аранжування творів були основою становлення виконавського репертуару для баяна та акордеона. Якщо иі інструменти з самого початку свого розвитку використовувались для виконання музики легких жанрів, тобто естрадних, $і$ ичей процес сприяв повноцінної популяризації баяно-акордеонного репертуару, то музиканту доводиться звертати увагу на обов 'язкову присутність естрадних n’єс у концертній програмі та адаптувати їх аранжування для свого виконання згідно із сучасними стилістичними вимогами.

Розвиток світового виконавського мистецтва народжує нові жанри і стилі, а сучасність актуалізує та розширює сферу їх вивчення та виконання.

У статті розкрито ключові питання пропонованої методики виконання творів естрадноджазових стилів на баяні й акордеоні, щцоб розширити стилістичні межі конщертного репертуару музиканта-викладача й музиканта-виконавця, збільшити силу враження авторських знахідок при підготуванні та виконанні естрадної й джазової імпровізащії та під час аранжування музичних творів у неоригінальних для них жанрах та стилях, адаптуючи під власне виконання та можливості баяна та акордеона. Все ие є основою демонстраиї оригінальності звучання інструмента $і$ має велику перевагу в плані підтримки популярності інструментального репертуару баяністів та акордеоністів.

Оновлення концертного репертуару музиканта-викладача й музиканта-виконавия у сенсі стилістичного збагачення музикою легкого жанру значно підвищить ланку популярності баяна й акордеона та сиенічний імідж виконавия.

Ключові слова: акомпанемент, аранжування, естрада, джаз, стиль, акордеон, баян, репертуар, жанр.

У розмаїтті інструментального виконавства баяно-акордеонне мистецтво виділяється своєю жанровою багатогранністю. Усі основні жанрово-стильові напрями композиторської та виконавської творчості присутні в концертних програмах сучасного баяніста і акордеоніста. Народний мелос, музична класика, твори легкого жанру та джазові композиції за останні роки все більше стають однаково затребуваними та актуальними в сфері баяно-акордеонного виконавства.

Аналіз методичних робіт, посібників, навчально-репертуарних збірників багатьох видатних музикантів-виконавців і науковців доводить, що дорога до престижної сцени баяніста та акордеоніста порядно багатогранна. Кожна робота, наприклад, "Школа джаза на баяне и аккордеоне" В. Власова, "Сучасна українська музика для баяна" А. Я. Сташевського, "Український "Модерн-Баян" - феномен світового мистецтва" І.Д. Єргієва, "Аранжування та обробки концертних творів для двох акордеонів" М. Черепанина, “Інтерпретація 
естрадно-джазових стилів в акордеонно-баянному виконавстві" М. Булди та ін. має свій підхід до методики виконання та збагачення репертуару. Кожен автор зі свого боку пропонує досить корисні пропозиції у даному ракурсі, але ж недостатньо глибоко розглядає область базових моментів виконання стилів музики легкого жанру.

Mema cmammi - розкрити ключові питання пропонованої методики виконання творів естрадно-джазових стилів на баяні й акордеоні, та розширити стилістичні межі концертного репертуару музиканта-викладача й музикантавиконавця. Збільшити силу враження авторських знахідок при підготуванні та виконанні естрадної й джазової імпровізації, та аранжування музичних творів у неоригінальних для них жанрах та стилях, адаптуючи під власне виконання та можливості баяна та акордеона.

Звернення до часів, коли “пісенно-танцювальні жанри були основними джерелами становлення репертуару" баяніста та акордеоніста, $\epsilon$ дещо нетрадиційним шляхом рішення проблеми оновлення сценічного іміджу виконавця. Першими виконавцями аранжувань пісень і танців були видатні музиканти того часу, такі як: “...Я. Орланський-Титаренко, Б. Богданов, П. Гвоздєв, П. Стригін, П. Рибаков, І. Паницький, тріо за участю О. Кузнецова, О. Данилова, Я. Попкова та ін. В Україні у 1930-х роках ці процеси також були пов'язані з академізацією баяна, поширювалися інструменти нової конструкції, що мали великий художньо-виражальний потенціал" [6, с. 45]. 3'ясовується, що баян та акордеон спочатку свого розвитку належав до інструментів, на яких виконавці грали музику легких жанрів, тобто естрадну.

Сьогодні ми розуміємо необхідність та цінність музики легкого жанру у виконанні на будь-якому музичному інструменті, тому що це просто стає модним.

Свінг, рок, вальс, полька та ін. - це стилі де естрадно-джазові жанри звучатимуть цікаво, якщо, головне, побудовано доступну, легку та ритмічну партію супроводження. I навпаки, якщо в аранжуванні п'єси ритмічна фрігура акомпанементу складено примітивно та непереконливо, то останній матеріал, включаючи добре виконану сольну партію, не зможе відтворити повноцінне враження на слухача через відсутність відчуття базових елементів стилю, характеру, які мають свій початок у партії супроводження.

Кожен музикант має міцні та слабкі місця у виконавчому матеріалі, тому для нього буде комфортніше вирішувати деякі завдання віртуозної гри у соло мелодії, коли акомпанемент впевнено підтримує та доповнює його творчі вимоги. Наприклад, коли правою рукою музикант не достатньо переконливо виконує деякі місця у тексті, то він повинен спростити їх, а тоді логічно та переконливо танцювальний ритм супроводження доповнить недостатню деталь в аранжуванні. Така схема рішення багатьох завдань виконавства легкої музики у нашому сьогоденні часто використовується при грі інструментальної та вокальної музики у музичних навчальних закладах естрадно-джазових відділень, а також на концертах, конкурсах, фрестивалях, де для музиканта є умови виконання під фронограму, "мінус" або з ансамблем чи, як мовиться, з ритм-секцією. В умовах сольного виконання такі поняття, як "мінус", "фонограма", "ритм-секція" слід розуміти як партія акомпанементу на лівої клавіатурі баяна чи акордеона. 
Різні види пам'яті музикант залучає, демонструючи свою роботу при виконанні твору. Основними видами пам'яті можна назвати: “зорову, музичну (музично-слухову) і м'язову (рухову)" [3, с. 149].

Зорова пам'ять музиканта здатна зберігати інформацію побачених певних образів чи предметів, одержану у процесі слухового сприйняття якого-небудь музичного твору. Наприклад, для найбільш цілеспрямованого ознайомлення 3 музичним матеріалом використовується нотний виклад. У репетиційному процесі при звучанні музики, музикант набагато уважніше звертає свою увагу на вигляд нотного друку, колір аркуша, номер сторінки тощо, та запам'ятовує як виглядає то, що він чує.

Музична пам'ять - це здатність музиканта розпізнавати музику на слух, граючи за допомогою музичного інструменту, виконуючи вокально чи прослуховуючи ії з іншого джерела звуковідтворення та запам'ятовувати музикальні фрази, гармонію, тощо.

М'язова пам'ять - це не менше унікальний психофізичний процес організму людини, що дає музикантові можливість запам'ятовувати і повторювати рухи граючих пальців, рухомих по клавіатурі музичного інструмента, під час прослуховування та, обов'язково, емоційного сприйняття музики.

Кожен вид пам'яті дуже та цілком залежать один від одного. Наприклад, у випадку втоми чи відволікання уваги одного з видів під час концертного виступу, інші миттєво підвищують свою активність та допомагають виконавцю утримувати баланс впевненості володіння матеріалу. “...рухове запам'ятовування, найтіснішим чином підтримує слухове, інший раз виручає його" [3, с. 149].

Ця методика не може обійтися без посилання безпосередньо до м'язової пам'яті, яка сприяє механічному запам'ятовуванню, на перший погляд, складному засвоєнню ритмічної схеми акомпанованого матеріалу. Він складається 3 ланок кожна з яких “автоматично - за принципом умовних рефлексів - тягне за собою наступну; свідомості ж досить "включити" першу ланку, вірніше - дати початковий сигнал, щоб весь ланцюжок розгорнувся сам собою" [2, с. 215].

Той факт, що партію лівої руки ми розглядаємо як ритм-секція чи акомпанемент, підкреслює її основну роль у механічному виконанні повторювальних ритмічних рисунків акомпанементу естрадно-джазового стиля.

Треба звернути увагу, що йдеться про гру на готовому інструменті, де, як здається, досить примітивні засоби виконання на його лівої частині, проте "басо-акордова система лівої клавіатури наших інструментів представляє в цьому випадку певні переваги й можливості" [1, с. 73]. Проте, грати твір, зберігаючи ритмічну модель акомпанементу естрадно-джазового стилю, виконуючи безліч синкоп у стилістичних фрраза-оборотах лівою рукою та частково правою, і водночас ще зберігати вільний художній інтерес, граючи правою рукою мелодію виглядає складним.

Не завадить розглянути деякі основні вимоги до виконання на баяні та акордеоні творів легких жанрів:

1. Виконання естрадно-джазових аранжувань передбачає вільну та імпровізовану подачу музикального матеріалу. Будь-яка фрактура має бути 
прозорою та збалансованою в сенсі загально-звукового насичення. Тому для контролю виконавець має можливість змінювати, спрощувати, адаптувати п'єсу у процесі гри, наприклад, “бажано використовувати гармонізацію та прикрашання ритм-фрази лівої руки у тих місцях, де відсутні акордові пласти в партії правої руки. Та, навпаки, якщо творчий задум вимагає імітації ритму в правій руці, то, звичайно, не буде зайвим контролювати баланс у гармонізації партії в лівій (наприклад, використовувати лише баси)" [4, с. 44].

2. Рух пальців рук виконавця має бути організований у сенсі ритму та метру, як рухи рук і ніг професійного естрадного барабанщика в значенні рівного і ясного подання музичного часу.

3. Штрихи акомпануючої частини аранжування в більшості випадків мають бути членороздільного характеру - це нон легато, стакато, акценти.

4. Виконання ритмічних фрігур бажано прослуховуватися настільки переконливо та зрозуміло, щоб почутий звук, мотив, фраза чи акорд, визначали в якому стилі, розмірі, місці такту п'єси вони звучать.

5. Перша частка такту має відчуватися якнайсильніше та впевнене часове місце в такті. Для цього виконання не потребує демонстрації (акцентів, тощо). Сильна частка має виконуватися злегка пасивно, навіть "гаснути" у паузі, але ж слабкі частки, образно кажучи, обстоюють значимість у звучанні ритмічної моделі акомпанементу, використовуючи відмінні прийоми штрихів.

6. Бажано довести виконання акомпануючої частини тексту до рівня автоматизму, щоб робота з динамікою, побудовою імпровізації в реальному часі, словом, з усіма іншими деталями підготування п'єси була легкою.

7. Одно з самих базових вимог естрадного виконавства, це зовнішній вигляд на сцені. Костюм, колір інструменту, місцезнаходження артиста на сцені, місцезнаходження мікрофрону, пюпітру, позитивний вираз на обличчі виконавця - все це повинно гармоніювати один з одним.

Деякі сучасні естрадно-джазові стилі які доступно і природно прозвучать у виконання на баяні та акордеоні:

Свіне. У музиці цього стиля четвертні тривалості поділяються на групи з трьох восьмих. Тому коли пишеться дві восьмі чи восьма з точкою та шістнадцята, то грати треба чверть з восьмою. Але це не класична тріоль. Перші дві восьмі задають темп, а третя, злегка акцентуючи й вступаючи трохи пізніше, додає відчуття синкопи та мікроуповільнення. Це і фрормує хитання свінгу, що на баяні чи акордеоні виконується несподівано просто, підкреслюючи слабку восьму кожної частки, при цьому легко натискуючи на міх.

Джаз-вальс. Джазовий стиль цій музики має дві назви, це вальс у джазовій обробці, або п'єса на три чверті у стилі свінг.

Діксі - це назва на місцевому сленгу одній 3 територій Півдня США середини 20-х - початку 40-х років XX ст. Здебільшого це яскравий, веселий стиль інструментальної та танцювальної музики. Діксілендом тоді називали групу музикантів з 4-5 осіб, що грали на контрабасі, банджо чи гітарі та духових.

Шафрл. Цей танцювальний стиль, який з'явився у м. Мельбурні (Австралія) наприкінці 80-х років XX ст. Грається у темпі приблизно від 150 до 200 ударів на хвилину. Злегка жорсткий характер музики, але свінг надає цьому стилю неповторність та своєрідність.

Самба. Тут свінгувати недоречно. Твори зі складними синкопами 
виконуються рівними восьмими. Підкреслювати синкопи цього стилю не варто натискуючи на міх (у кожному такті синкоп досить багато). Прийоми, як пальцевий удар чи поштовх у рівному веденні міха будуть достатні. Монтуно, клаве, тумбао - це основоположні ритм-фррази в акомпанементі латиноамериканських.

У босанові характер музики спокійний та ліричний, і прослуховується більш скупчена гармонійна фактура. Цей стиль виглядає майже так само, як самба, але звучить у більш стриманому темпі.

Ча-ча-ча та Румба - кубинські танці. Виконується також у розмірі чотири чверті. Якщо Ча-ча-ча виконується у темпі - 125 ударів на хвилину, то Румба в більш повільному темпі та в мінорному ладі (в більшості має характер смутку).

Рок-балада. Взагалі рок-музика - це мистецтво, що об'єднує в собі велику кількість напрямів, жанрів і стилів. У рок-баладі виконуються безліч творів сучасної естрадної та джазової культури. Інструментальна музика в цьому стилі має рівний та прозорий за фрактурою ритм і характер ліричної композиції.

Диско - один з основних жанрів танцювальної музики 1970-х.

Поп-твісm утворився у США в 1960-х роках спочатку як танцювальний жанр. Життєрадісна та енергійна музика характеризує цей стиль.

Старий, добрий Рок-н-ролл. Один зі стилів поп-музики 1950-х років. Сплав елементів блюзу та кантрі народили цій цікавий вокально-інструментальний та танцювальний стиль. Чіткий ритм, розкутість, імпровізаційність - базові риси рок-н-ролла.

Xiп-хоп з'явився у 1974 р. серед кварталів Бронкса м. Нью-Йорк, під впливом деяких елементів субкультури: емсіінга (абревіатура назви Master of Ceremonies, де співак імпровізаційно вимовляє слова у стилі реп у супроводі електронної танцювальної музики), діджеінга (прийоми діджея), брейкданса та образотворчого мистецтва графрimi. Хіп-хоп за характером музики дещо нагадує шафол, але стилістичні особливості й акомпанемент зовсім інші.

Найпопулярніший на сьогодні музичний стиль і танець - Реггетон. Виник у кінці 1990-х років в Пуерто-Ріко під впливом ритмики ямайської реггі, репу, денсхолла і хіп-хопу, де тексти зазвичай читаються на іспанскої мові. Дуже поширений у латиноамериканських країнах Карибського басейну та в США.

Висновки та перспективи подальших досліджень. При сучасному виконанні аранжувань для баяна та акордеона обов'язково враховується звукотемброва специфіка їх звучання. Інструментам притаманна ціла низка технічних акустичних особливостей, які можуть бути недоліком в одній ситуації та перевагою - в іншій. Зрозуміло, що це впливає на виконання певних музичних творів виграшно, а для інших - навпаки. Все це є основою у сенсі демонстрації оригінальності звучання інструмента і має велику перевагу в підтримки популярності інструментального репертуару баяністів та акордеоністів. Тому робити та виконувати “аранжування треба таким чином, щоб слухач сприймав твір як музику, що написана саме для інструменту, звучання котрого він слухає" [5. с. 96].

Оновлення концертного репертуару музиканта-викладача й музикантавиконавця у сенсі стилістичного збагачення музикою легкого жанру значно підвищить ланку популярності баяна й акордеона та сценічний імідж виконавця. 


\section{Використана література:}

1. Власов В. Школа джаза на баяне и аккордеоне : уч. пособ. Одеса : Астропринт, 2008. 160 с.

2. Коган Г. М. У врат майстерства. Работа пианиста. Москва : Музыка, 1969. 344 с.

3. Липс Ф. Искусство игры на баяне. Москва : Музыка, 1985. 160 с.

4. Стрельченко К. Практичний курс естрадно-джазового акомпанементу для баяна та акордеона : навч.-метод. посіб. для студ. вищ. мистецьких навч. закл. / Київ. ун-т ім. Б. Грінченка, Ін-т мистецтв. Київ : Київ. ун-т ім. Б. Грінченка, 2014. 172 с.

5. Стрельченко К. Сучасні аранжування та перекладення п'єс для баяна й акордеона в аспекті звукотембрової специфіки інструментів. Музичне мистецтво в освітологічному дискурсі: науковий журнал / Київ. ун-т ім. Б. Грінченка ; ред-кол. : О. М. Олексюк, Л. Л. Хоружа, Л. А. Бондаренко та ін. Київ,2017. № 2. 178 с.

6. Черепанин М., Булда М. Естрадний олімп акордеона : монографія. Ивано-Франківськ : Лілея-НВ, 2008. $256 \mathrm{c}$.

\section{References:}

[1] Vlasov, V. (2008). Shkola dzhaza na bayane i akkordeone: uch. posob. Odesa : A stroprint, $160 \mathrm{~s}$.

[2] K ogan, G. M . (1969). U vrat majsterstva. Rabota pianista. M oskva : M uzyka, 344 s.

[3] Lips, F. (1985). Iskusstvo igry na bayane. M oskva : M uzyka, $160 \mathrm{s.}$

[4] Strelchenko, K. (2014). Praktichnij kurs estradno-dzhazovogo akompanementu dlya bayana ta akordeona: navch.-metod. posib. dlya stud. vish. misteckih navch. zakl. / K iyiv. un-t im. B. Grinchenka, In-t mistectv. Kiyiv : K iyiv.un-t im. B. Grinchenka, $172 \mathrm{~s}$.

[5] Strelchenko, K . (2017). Suchasni aranzhuvannia ta perekladennia pies dlia baiana y akordeona $v$ aspekti zvuko-tembrovoi spetsyfiky instrumentiv. Muzychne mystetstvo v osvitolohichnomu dyskursi: naukovyi zhurnal / K yiv. un-t im. B. H rinchenka; red-kol. : O. M. Oleksiuk, L. L. K horuzha, L. A. Bondarenko ta in. K yiv, № 2. $178 \mathrm{~s}$.

[6] Cherepanyn, M ., Bulda, M. (2008). Estradnyi olimp akordeona : monohrafiia. Y vano-Frankivsk : Lileia$\mathrm{NV}, 256 \mathrm{~s}$.

\section{СТРЕЛЬчЕНко К. М. Методика исполнения произведений на баяне и аккордеоне в естрадно-джазовых стилях.}

Суть этой работы заключается в практическом применении инноващионного подхода к обновлению конщертного репертуара баяниста $u$ аккордеониста $c$ точки зрения легкожанровости исполнительской программы. В приниипе, это обращение к тем временам, когда песенно-танцевальные аранжировки произведений были основой становления исполнительского репертуара для баяна и аккордеона. И если эти инструменты с самого начала своего развития использовались для исполнения музыки легких жанров, то есть эстрадных, и этот прочесс способствовал полноченной популяризации баяно-аккордеонного репертуара, то сегодня музыканту следует обращать внимание на обязательное присутствие эстрадных пьес в кониертной программе и адаптировать их аранжировки для своего исполнения согласно современным стилистическим требованиям.

Развитие мирового исполнительского искусства рождает новые жанры и стили, а современность актуализирует и расширяет сферу их изучения.

В статье раскрыты ключевые вопросы предлагаемой методики исполнения произведений эстрадно-джазовых стилей на баяне и аккордеоне, чтобы расширить стилистические границы конщертного репертуара музыканта-педагога и музыканта-исполнителя, увеличить силу впечатления авторских находок при подготовке и исполнении эстрадной и джазовой импровизации и аранжировки музыкальных произведений в неоригинальных для них жанрах и стилях, адаптируя под собственное исполнение и возможности баяна и аккордеона. Все это является основой демонстрации оригинальности звучания инструмента и имеет большое преимущество в плане поддержсания популярности инструментального репертуара баянистов и аккордеонистов. Обновление конщертного репертуара музыканта-педагога и музыкантаисполнителя в смысле стилистического обогащения музыкой легкого жанра значительно 
повысит звено популярности баяна и аккордеона и сценический имидж исполнителя.

Ключевые слова: аккомпанемент; аранжировка; эстрада; джаз; стиль; аккордеон; баян; репертуар; жанр.

STRELCHENKO K. M. Methods of play the accordion of pieces of music in pop and jazz styles.

The essence of this article lies in the practical application of an innovative approach to updating the concert repertoire of an accordionist in terms of playing pieces of light genre. Basically, this is an appeal to that period when the instrumental arrangements of songs and dances were the basis for the formation of the performing repertoire for the accordion. If these instruments from the very beginning of their development were used to play music of light genres, that is, pop music, and this process contributed to the full popularization of instruments, then the musician should pay attention to the obligatory presence of pop pieces in his concert program and try to adapt arrangements accordin for modern stylistic requirements.

The development of world performing art gives rise to new genres and styles, and modernity actualizes and expands the sphere of their study.

The article reveals the key issues of the proposed methodology for performing works of pop-jazz styles on the button accordion and accordion, to expand the stylistic boundaries of the concert repertoire of the musician-teacher and musician-performer, to increase the power of impression of copyright finds in the preparation and execution of pop and jazz improvisation and arranging musical works in non-original genres and styles for them, adapting to their own performance and the capabilities of the button accordion and accordion. All this is the basis for demonstrating the original sound of the instrument and has a great advantage in terms of maintaining the popularity of the instrument repertoire of accordionists and accordionists. Updating the concert repertoire of the musician-teacher and musician-performer in the sense of stylistic enrichment with light genre music will significantly increase the link of the accordion and accordion and the stage image of the performer.

Keywords: accompaniment; arrangement; jazz; style; accordion; repertoire; genre.

DOI: https://doi.org/10.31392/NZ-npu-142.2019.25

УДК 378.091.3-051:78(477)(092)

Ткачук В. В.

\section{МЕТОДИЧНІ ЗАСАДИ ВИКОРИСТАННЯ МИСТЕЦЬКО-ПЕДАГОГІЧНОГО ДОРОБКУ М. КОЛЕССИ У ФАХОВІЙ ПІДГОТОВЦІ МАЙБУТНІХ УЧИТЕЛІВ МУЗИКИ}

Стаття присвячена аналізу багатогранної діяльності М.Колесси - одного 3 найвидатніших українських музикантів ХХ століття - композитора, диригента, педагога, просвітителя. Музичний доробок композитора досліджується з огляду на події його життя, а також крізь призму сочіально-культурного фону, який супроводжував його діяльність протягом багатьох років. Окреслюються основні напрямки впровадження у навчальний процес фахової підготовки студентів музичної спадщини М. Колесси, а також його педагогічної системи виховання диригента. Вивчати композиторський доробок М. Колесси варто з позииій професійного осмислення народної творчості, поєднання народно-пісенної традииії 3 сучасними стильовими експериментами. Розкрито педагогічний потенціал інструментальних 